Acta Universitatis Nicolai Copernici • Pedagogika XXIX/2013

Nauki Humanistyczno-Społeczne • Zeszyt 421

http://dx.doi.org/10.12775/AUNC_PED.2013.005

Monika Kamper-Kubańska

Państwowa Wyższa Szkoła Zawodowa we Włocławku

\title{
WiesŁawa Aleksandra Sacher, Pedagogika muzyki. Teoretyczne podstawy POWSZECHNEGO KSZTALCENIA MUZYCZNEGO, IMPULS, KRAKów 2012, ss. 319
}

Droblematyka pedagogiki muzyki trudna jest do jednoznacznego L określenia, albowiem koncentruje się wokół wielu zagadnień związanych z muzyką jako dziedziną sztuki, ale i przedmiotem nauczania. To właśnie na tej płaszczyźnie podejmowane są zagadnienia związane z kształceniem i wychowaniem w obrębie pedagogiki muzyki.

Rozwój nowych technologii, a także zaawansowanie badań nad rolą muzyki spowodowały, że stała się ona zauważalna i jest coraz częściej wykorzystywana w wielu aspektach życia jednostki - począwszy od wspierania rozwoju w toku życia, aż po funkcje usługowe (np. wykorzystanie muzyki do celów marketingowych).

Wieloaspektowość samej muzyki powoduje, że rozpatrywanie jej w kontekście rozwojowym wciąż daje nowe pola poznawcze, a dzieje się tak dlatego, że muzyka nie jest jednoznaczna, nie da się jej w sposób „sztywny” zdefiniować. Można pokusić się o stwierdzenie, że ilu ludzi, tyle definicji muzyki. Owa wieloznaczność wynika przede wszystkim z tego, że dla każdego z nas z osobna, ale i dla każdej grupy muzyka ma inne znaczenie, inaczej oddziałuje, niesie inny bagaż doświadczeń i emocji. Owa „nieokreśloność” z jednej strony nastręcza trudności $\mathrm{w}$ jednoznacznym zdefiniowaniu muzyki i jej roli w procesie uczenia - 
nauczania - wychowania, a z drugiej strony daje możliwość budowania wciąż nowych sytuacji pedagogicznych, które pozwalają wesprzeć rozwój każdej jednostki.

Autorka recenzowanej pracy zwraca uwagę, że „dyskurs obejmujący problematykę powszechnego kształcenia muzycznego w kontekście współczesnej kultury, prowadzony już od wielu lat przez pedagogów muzyki, artystów muzyków oraz kulturoznawców, zmusza do namysłu nad jakością kształcenia muzycznego, nad jego formami realizacyjnymi, czy w końcu nad jego celami. Niezgodność w poglądach na rolę muzyki popularnej w powszechnym kształceniu muzycznym nie jest czymś niekorzystnym. Zmusza bowiem do rozpatrywania tego ważnego zagadnienia wielowarstwowo, do podejmowania prób nadania temu obszarowi kultury muzycznej właściwego miejsca zarówno w codzienności, jak i edukacji" .

W polskim systemie edukacji kształcenie muzyczne stało się powszechne, ale nie zawsze jego realizacja, owa powszechność, niesie za sobą wysoką jakość. Niejednokrotnie kształcenie muzyczne przybiera formę pozorowanej edukacji, a muzyka staje się ledwie tłem, np. do zabaw, bez rzeczywistego wprowadzenia dzieci w świat muzyki.

Recenzowana książka stanowi podsumowanie doświadczeń zawodowych autorki, porusza tematykę edukacji muzycznej w wielu aspektach, aby w sposób najpełniejszy ukazać znaczenie muzyki w rozwoju jednostki.

Rozważania ujęte zostały w pięciu rozdziałach podzielonych na podrozdziały.

W rozdziale pierwszym opisano źródła pedagogiki muzyki i jej miejsce wśród nauk o wychowaniu. W części tej autorka prowadzi rozważania począwszy od filozoficznych źródeł kształcenia muzycznego, poprzez próbę naukowego uzasadnienia dla powszechnej edukacji muzycznej, aż po ukazanie pedagogiki muzyki w systemie nauk i założeń metodologicznych i metodycznych w odniesieniu do pedagogiki muzyki.

1 W. A. Sacher, Pedagogika muzyki. Teoretyczne podstawy powszechnego kształcenia muzycznego, Kraków 2012, s. 11-12. 
Treści zawarte w tej części książki stanowią nie tylko wprowadzenie $\mathrm{w}$ problematykę, ale nade wszystko dają bazę do rozważań nad znaczeniem edukacji muzycznej w procesie nauczania i wychowania oraz pokazują, że muzyka towarzyszy człowiekowi od zarania dziejów i jej znaczenie dostrzegali już starożytni filozofowie, a ich myśli rozwijane były w wiekach późniejszych aż po dziś dzień. Warto przytoczyć w tym miejscu słowa Pitagorasa czy fragment listu Marcina Lutra.

Pitagoras uznał liczbę za źródło wszelkiego bytu. Sądził, że „niebiosa są jak gama muzyczna, że gwiazdy wydają harmonijne dźwięki, a najdoskonalsze dusze muszą być zawsze harmonijnie zestrojone $\mathrm{z}$ niebiosami"2.

Marcin Luter uznał, że „muzyka jest dyscypliną, która czyni ludzi cierpliwszymi, łagodniejszymi, skromniejszymi i rozumniejszymi [...], przepędza złego ducha i napawa szczęściem. Dzięki muzyce zapomina się o gniewie oraz o wszystkich grzechach [...]. Muzyka jest najskuteczniejszym balsamem, co uspokaja, rozwesela i ożywia serca tych, którzy smucą się i cierpią [...]. Należy zaznajomić młodych z tą sztuką, gdyż czyni ona ludzi dobrymi, delikatnymi i gotowymi do wyrzeczeń"3.

Autorka dokonała rzetelnej analizy podstaw filozoficznych i teoretycznych edukacji, pedagogiki muzyki, co pozwoliło swobodnie przejść do rozważań zawartych w dalszych rozdziałach recenzowanej publikacji.

Rozdział drugi i trzeci poświęcone zostały zagadnieniom badań nad powszechnym kształceniem muzycznym oraz założeniom teoretycznym powszechnego kształcenia muzycznego. W obu częściach autorka starała się w sposób rzetelny i pełny ukazać przestrzenie powszechnego kształcenia muzycznego począwszy od zagadnień rozwoju muzycznego, poprzez zdolności, preferencje muzyczne, wspomaganie rozwoju dyspozycji umysłowych i fizycznych, po skuteczność nauczania muzyki i kształcenie nauczycieli oraz cele, treści, formy i metody wykorzystywane w procesie kształcenia i wychowania muzycznego.

Uważam, że należy szczególną uwagę zwrócić właśnie na te dwa rozdziały, albowiem w nich najwyraźniej widać, że autorka nie odwo-

\footnotetext{
2 Tamże, s. 17.

3 Tamże, s. 23.
} 
łuje się tylko i wyłącznie do literatury przedmiotu, ale także do doświadczeń własnych i z tego też powodu części te nie przyjmują charakteru suchego sprawozdania, lecz rzetelnej oceny praktyka, który problematykę wychowania muzycznego poznał zarówno z perspektywy nauczyciela muzyki, jak i wykładowcy akademickiego kształcącego nowe pokolenia nauczycieli.

W dobie ciągłych pytań o miejsce muzyki w szkole, o rolę nauczyciela i proces kształtowania pedagogów, myślę, że warto przytoczyć słowa autorki zaczerpnięte $\mathrm{z}$ podsumowania rozdziału trzeciego: nauczyciel wpływa na swoich uczniów, kształtuje ich postawy i sposoby myślenia, wprowadza w nieznany im jeszcze świat, przyszły świat. Jest ponadto i odbiorcą i twórcą kultury. Od jego stosunku więc - krytycznego bądź konformistycznego, pogłębionego lub powierzchownego - będzie w pewnym stopniu zależeć kształt kultury, którą wypracowuje następne pokolenie" 4 .

Zacytowane słowa odnoszą się zarówno do nauczycieli muzyki, jak i innych przedmiotów. Ich oczywistość jest widoczna, lecz autorka ukazuje tutaj problem swoistej odpowiedzialności za rozwój i wykorzystywanie różnych przestrzeni kulturalnych w procesie wychowania i kształcenia nowych pokoleń. Odwieczne pytania o muzykę i jej miejsce w procesie wspierania, można by rzec, całożyciowego rozwoju jednostki ukazują, że my jako pedagodzy winniśmy uczyć się holistycznego podejścia do tego zagadnienia, aby w kluczowych dla rozwoju momentach nie przerzucać się odpowiedzialnością i nie zasłaniać brakiem kompetencji w sytuacji, kiedy mamy kształcić i wychowywać człowieka potrafiącego poruszać się w obszarze szeroko rozumianej kultury. Muzyka jest dobrym przykładem przestrzeni, którą można wykorzystać w procesie wychowania, uczenia i nauczania wszystkich jednostek, niezależnie od stopnia rozwoju czy występujących dysfunkcji rozwojowych.

Ostatnie dwa rozdziały zostały poświęcone problematyce pozaszkolnego kształcenia muzycznego i systemom powszechnej edukacji muzycznej w wybranych krajach Europy i świata. Części te stanowią dopełnienie podjętych rozważań i obrazują miejsce muzyki w życiu

\footnotetext{
4 Tamże, s. 229.
} 
człowieka, zarówno w formie zinstytucjonalizowanej, jak i przeżyć własnych (np. jako forma spędzania wolnego czasu).

Wiesława Sacher w swoim opracowaniu celowo pomija obszar kształcenia artystycznego, który często bywa identyfikowany z pojęciem wychowania i kształcenia muzycznego. Uważam, że taki zabieg był nie tylko prawidłowy, ale wręcz konieczny do tego, aby obalić mit iż wychowanie muzyczne jest dla wybranych i powinno skupiać się tylko w przestrzeni szkolnictwa artystycznego.

Reasumując, warto postawić pytanie: do kogo adresowana jest ta pozycja książkowa? Z całą pewnością, odwołując się także do doświadczeń własnych, uważam, że odbiorcami powinni być nie tylko muzycy, nauczyciele muzyki, ale przede wszystkim pedagodzy, niezależnie od obszaru swoich zainteresowań, albowiem głęboka eksploracja tematu ukazuje rolę i znaczenie wykorzystania muzyki jako wytworu kultury w procesie szeroko rozumianego rozwoju i dlatego każdy pedagog znajdzie tu przestrzeń dla siebie do dalszych analiz. Postawione pytania, ukazane tropy nie wyczerpują całej wiedzy z zakresu podjętej problematyki, co moim zdaniem stanowi o wartości niniejszego opracowania. Jego autorka nie rości sobie praw do wiedzy absolutnej, uchyla zaś różne drzwi, zapraszając do świata muzyki wszystkich chcących ten świat poznać, w myśl założeń Bogusława Schaeffera, który zwrócił uwagę, że „kraina muzyki jest krainą bezbrzeżną”"

${ }^{5}$ B. Schaeffer, Dzieje kultury muzycznej, Warszawa 1998, s. 8. 
